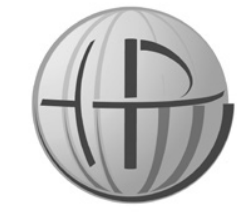

Horyzonty Polityki 2020, Vol. 11, No 34 OPEN ACCESS

\section{Jacek Surzyn}

http://orcid.org/0000-0001-7959-243X Akademia Ignatianum w Krakowie

Wydział Filozoficzny Instytut Filozofii e-mail: jacek.surzyn@ignatianum.edu.pl

DOI: $10.35765 / H P .1861$

\title{
Projekt wieczystego pokoju. Polityczne marzenie wielkiego filozofa
}

\section{Streszczenie}

CEL BADAWCZY: Celem artykułu jest przedstawienie projektu wiecznego pokoju Immanuela Kanta pod kątem jego filozoficznych i politycznych założeń.

PROBLEM I METODY BADAWCZE: Głównym problemem analizowanym w tym tekście jest ukazanie roli myślenia teoretycznego i jego politycznych implikacji. Filozofia krytyczna Kanta wyznaczyła nową drogę refleksji filozoficznej. Zasadniczo filozofowanie po Kancie okazało się niemożliwe bez odniesienia do jego myśli (czy to w sensie pozytywnym, czy też negatywnym). W ramach myśli filozofa pojawiła się także refleksja polityczna. Ważnym miejscem w tej refleksji wydaje się określenie ogólnego celu ludzkości, którym, według Kanta, jest dążenie do wiecznego pokoju.

PROCES ARGUMENTACJI: Artykuł próbuje opisać projekt wiecznego pokoju Kanta z punktu widzenia problemu jego wykonalności. Ta kwestia ujawnia podstawowy problem refleksji nad polityką, czyli powiązania teorii z praktyką.

WYNIKI B ADAŃ: Filozofia jest czysto intelektualną spekulacją której idee odnoszą się jednak do praktyki politycznej. W tym kontekście można zastanowić się, czy "sny” filozofów-teoretyków mają zastosowanie w praktycznym (realnym) świecie.

WNIOSKI, IN NOWACJE I ZALECENIA: We wnioskach próbuje się wykazać pierwszeństwo namysłu teoretycznego nad praktycznym wdrażaniem 
koncepcji politycznych w życiu społecznym. Kant - jako filozof - pokazuje, że idee i różne teoretycznie ustalone cele, które stanowią wyzwanie dla człowieka i społeczeństwa, mają sens jedynie jako postulaty a priori, a te dopiero wdrażane w praktyce stają się właściwymi celami do osiągnięcia.

\title{
SŁOWA KLUCzowe:
}

wieczny pokój, projekt filozoficzny, polityka i filozofia, teoria i praktyka

\author{
Abstract \\ PERPETUAL PEACE - A POLITICAL DREAM \\ OF THE GREAT PHILOSOPHER
}

RESEARCH OBJECTIVE: The aim of this paper is an analysis of Kant's project of perpetual peace in point of view his philosophical and political concequences.

THE RESEARCH PROBLEM AND METHOD: The main problem undertaken in this text is to show the role of theretical thinking (dreaming) and its political (real) implications. Immanuel Kant and his critical philosophy set a new path of philosophical reflection in modern times. In principle, philosophizing after Kant has been impossible without reference to his thought (whether in a positive or negative sense). Kant's achievements also included political reflection. An important place in this reflection it seems to be to define the general purpose of humanity, which, according to Kant, is the pursuit of eternal peace.

THE PROCESS OF ARGUMENTATION: The article attempts to describe Kant's peaceful project from the perspective of the problem of its feasibility. This issue reveals the fundamental problem of reflection on politics, that is, relating theory to practice.

RESEARCH RESULTS: Philosophy is purely intellectual speculation whose ideas relate to the practice of political life. In this context, one can consider whether the "dreams" of theoretician philosophers have any application in the practical (real) world.

CONCLUSIONS, INNOVATIONS, AND RECOMMENDATIONS: The conclusions attempt to show the priority of theoretical reflection over the practical implementation of political concepts in social life. Kant as a philosopher shows that the ideas and various goals facing man and society make sense only as a priori postulates that become real goals to accomplish. 


\section{KeYwORDS:}

perpetual peace, philosophical project, politics and philosophy, theory and practice

\section{WPROWADZENIE: FILOZOFICZNE PARADYGMATY A RZECZYWISTOŚĆ POLITYCZNA}

Namysł nad rzeczywistością polityczną obciążony jest zawsze jakimiś założeniami ontologicznymi. Mogą mieć one dwojaki charakter. W najogólniejszym wymiarze sprowadzają się albo do przyjęcia obiektywnego (czyli niezależnego od podmiotu poznającego) istnienia zasad i aksjomatów determinujących postrzeganie życia wspólnotowego i wtedy możemy w uproszczeniu mówić o podejściu realistycznym, albo też założenia mogą przybierać postać subiektywnych zasad i aksjomatów i w tym wymiarze odwołują do podstawy, którą jest podmiot poznający. W filozofii nowożytnej sprowadziło się to do epistemologicznej dyskusji na temat źródła poznania, co z kolei skutkowało wypracowaniem dwóch przeciwstawnych stanowisk: z jednej strony racjonalizmu odwołującego się do apriorycznych źródeł poznania, $z$ drugiej strony - do genetycznego empiryzmu, który zakładał aposterioryczny charakter ludzkiej wiedzy. Innymi słowy, racjonaliści wskazywali na wrodzony charakter ludzkiej wiedzy, podczas gdy empiryści przeciwnie - zakładali, że człowiek rodzi się jako „pusta tablica” i cała jego wiedza wywodzi się z doświadczenia.

Obie wizje stały się wyjątkowo popularne wśród humanistów. Kształtują również sposoby postrzegania i opisu rzeczywistości politycznej, w tym rzeczywistości stosunków międzynarodowych. Podobnie jak w innych dziedzinach ludzkiej wiedzy również w badaniach stosunków międzynarodowych pojawiły się liczne spory i dyskusje dotyczące wypracowania wspólnej podstawy badawczej (Aron, 1968, s. 4-12; Vasques, 1982, s. 3-28). Spory te mają niejako "strukturalny" charakter i są nieusuwalne, gdyż wiążą się z przyjęciem w zasadzie nieweryfikowalnych wizji postrzegania relacji międzynarodowych, co doprowadziło do sformułowania paradygmatów stosowanych do opisu rzeczywistości politycznej. Owe paradygmaty odwołują się zawsze do wskazanych na początku filozoficznych założeń 
(ontologicznych i epistemologicznych) i dlatego można wyróżnić trzy ich typy: realistyczny, liberalny-idealistyczny i pluralistyczny ${ }^{1}$. Realistyczny paradygmat wydaje się przy tym najstarszy i wskazuje na fundamentalną pozycję państwa w relacjach międzynarodowych. Państwo przybiera postać bytu ontologicznego i ma pełną ontyczną autonomię, jest zatem realnym, obiektywnym tworem stanowiącym podstawę wszelkich relacji. W takim ujęciu najsławniejszą koncepcją paradygmatu realistycznego jest Platońska propozycja państwa idealnego. Inny jest paradygmat pluralistyczny, który historycznie często wiąże się z poglądami Immanuela Kanta. W prezentowanym tekście chciałbym skupić się właśnie na jego koncepcji i na tym przykładzie pokazać pewien specyficzny problem kształtujący wzajemną zależność filozofii i polityki. Myśl Kanta wydaje się szczególnie dobrym polem badawczym, gdyż znakomicie ilustruje być może jeden z najważniejszych dylematów badań politologicznych w ogóle, to znaczy problem uzgodnienia przydatności reguł-praw życia wspólnotowego uzyskanych wyłącznie drogą czysto rozumową (zatem a priori) $\mathrm{w}$ opisywaniu, a $\mathrm{w}$ zasadzie $\mathrm{w}$ kształtowaniu praktycznego obszaru relacji międzyludzkich, $w$ tym międzynarodowych. Chodziłoby zatem o użyteczność teoretycznego modelu w praktyce życia politycznego. Przykładem w tej materii może być sławny Kantowy projekt wiecznego pokoju.

\section{DYCHOTOMIA TEORII I PRAKTYKI}

Immanuela Kanta nie postrzega się w pierwszym rzędzie jako myśliciela-teoretyka politycznego. W powszechnej opinii dominuje pogląd o jego dokonaniach w obszarze filozofii, które wiążą się z transcendentalizmem, „przewrotem kopernikańskim” czy oparciem moralności na imperatywach. Uznaje się go także za fundatora Oświecenia, część badaczy skłonna jest uznać również za myśliciela, który jest ważny w kontekście rozważań religijnych. Zgadzając się z takim usytuowaniem intelektualnych dokonań Kanta należy jednak

1 Nazwy są umowne i można spotkać różne określenia owych paradygmatów. Ja odwołałem się do podziału i opisu podanego w części metodologicznej w książce: Stosunki międzynarodowe. Geneza, struktura, dynamika (s. 36-37). 
podkreślić jego aktywność w obszarze szeroko pojętej polityczności i samej polityki ${ }^{2}$. W grę wchodzi tu w zasadzie odwieczny problem pewnego napięcia, które występuje pomiędzy namysłem teoretycznym $\mathrm{z}$ jednej strony a praktyką działania z drugiej. Innymi słowy, w koncepcji Kanta pojawia się nienowy dylemat związany z tym, w jaki sposób (jeśli jest to w ogóle możliwe) przejść od teoretycznej konstrukcji, będącej próbą opisu rzeczywistości, do jej praktycznego zastosowania, co w zasadzie może okazać się ostateczną weryfikacją słuszności czy nawet prawdziwości danej konstrukcji teoretycznej.

Zależność teorii od praktyki (lub lepiej - związek teorii z praktyką) unaoczniła się bardzo wcześnie już w staroży tnej Grecji, gdzie u samego zarania cywilizacji helleńskiej w momencie narodzin filozofii pojawił się jej konflikt z polityką. Polityka w tym wczesnym okresie organizowała życie wspólnotowe, uzasadniając konieczność istnienia takiego a nie innego porządku społeczno-politycznego i prawo do sprawowania władzy. Najogólniej mówiąc, w tym zastanym politycznym paradygmacie relacje $\mathrm{w}$ ramach wspólnoty były sankcjonowane na podstawie tradycji i szeroko pojmowanych więzów krwi, co dawało wystarczającą legitymację do rządzenia. Filozofia rodząca się początkowo w koloniach greckich (obszar Jonii, a później południe Półwyspu Apenińskiego - Sycylia i Sardynia) postawiła na radykalnie odmienne tłumaczenie konieczności istnienia porządku politycznego, więc tym samym zmieniła rozumienie samej polityki i tego, co możemy nazwać „ppolitycznością” ${ }^{3}$. Filozofia od zarania rościła sobie prawo do poznania „wszystkiego”, zatem konstytuowała się jako wiedza uniwersalna i powszechna. W rezultacie filozofia musiała być także „ahistoryczna" w tym znaczeniu, że tradycja i dotychczasowy zastany porządek rzeczywistości w rozważaniach filozoficznych nie

2 Podkreśla się, że polityka u Kanta ma specyficzny wymiar. Można przytoczyć na przykład następującą opinię: „Politik-Begriff [...] bei Kant eine erhebliche Einschränkung, sozusagen einen Funktionsverlust [erfährt], weil Politik in Recht und Ökonomie überführt wird" (Koslowski, 1985, s. 36).

3 Wśród bogatej literatury dotyczącej tego zagadnienia wydaje się, że dwie pozycje zasługują na szczególne wyróżnienie. Pierwsza to książka Christiana Meiera pod tytułem Powstanie polityczności u Greków. Druga pozycja to książka pokazująca związki filozofii i polityki oraz dynamiczne napięcie między nimi w czasach antycznej Grecji, której autorem jest równie ważny jak Meier badacz tych zagadnień Eric Voegelin (Świat Polis). 
mogą odgrywać żadnej roli, ponieważ filozofia podąża do poznania i wskazania na jeden początek, na jedną podstawę „,absolutną", „obiektywną", „niepodważalną" i nieuzasadnialną już przez nic innego ${ }^{4}$. Uzurpująca sobie takie prawa filozofia musiała stanąć do konfrontacji z polityka, którą zdewaluowała jako wiedzę uzasadniającą porządek społeczny w sposób fałszywy poprzez odwołania do przeszłości, że na przykład zawsze było tak i tak, zatem tak musi być również teraz i w przyszłości. Takie rozumowanie z perspektywy filozoficznej wydawało się nie do utrzymania, dlatego sformułowanie nowej polityki stało się zadaniem, którego świadomi byli filozofowie i co doskonale dostrzegał na przykład Platon. W związku z tym napisał dzieło pod tytułem Państwo, będące teoretyczną próbą opisania idealnego, to znaczy ostatecznego, prawdziwego i niepodważalnego porządku społeczno-politycznego, służącego naprawieniu i zniwelowaniu wszelkich konfliktów, które w relacjach politycznych istnieją. Obraz państwa-kaliopolis doskonałego jest czysto teoretycznym konstruktem przedstawiającym właściwy porządek społeczny oparty na harmonii między wewnętrznym porządkiem człowieka a jego zewnętrzną eksplikacją. Teoretyczny konstrukt Platona pokazuje jak powinno (musi?) być i bardzo wyraźnie wskazuje cel, do którego człowiek winien dążyć, a to już bezpośrednio łączy się z praktyką. Pojawia się zatem pytanie, czy państwo idealne, będąc idealnym i w tym znaczeniu nierealnym, utopijnym projektem, można zrealizować praktycznie? Jak wiadomo, sam Platon w pewien sposób pokazał istotę owego dylematu i jego dychotomiczność poprzez swą nieudaną wyprawę do Syrakuz. Osobista klęska ateńskiego filozofa być może zaważyła na późniejszym ujmowaniu relacji teorii do praktyki i tym samym filozofii do polityki, w której stale starano się podporządkować jedną drugiej, to znaczy albo ignorować praktykę, albo weryfikować teorię za pomocą praktyki. Wiązało się to ze specyficznym typem postaw odrzucających sens teoretycznego namysłu w praktycznym zastosowaniu lub też nie akceptujących

4 Można przywołać postulat Arystotelesa, który wprawdzie wypowiadał się o zasadzie niesprzeczności, ale w znaczeniu ogólnym reguła ta dobrze opisuje sens istnienia jednego początku czy jednej podstawy. Chodzi mianowicie o znalezienie czegoś, od czego wszystko inne (cokolwiek) jest zależne, a owo coś nie jest już zależne od niczego innego. 
znaczenia praktycznego doświadczenia w odniesieniu do teoretycznego konstruktu.

\section{OŚWIECENIOWY SPÓR FILOZOFII I POLITYKI}

Zarysowana kwestia nabrała szczególnego znaczenia w okresie Oświecenia. Racjonalizm i nacisk na empiryzm związany z dynamicznymi zmianami wizji świata, w której stopniowo odchodzono od niepodważalnych dogmatów, spór filozofii (teorii) z polityką (praktyką) sprowadziły na nowe tory. Rozpoczęło się poszukiwanie nowego ładu społecznego opartego na założeniu bezwzględnej wolności jednostki, ontologicznego indywidualizmu, a także na "a-naturalności" życia wspólnotowego. Wszystko to miało być podbudowane niepodważalnymi racjami płynącymi z samego rozumu i ze zweryfikowanych empirycznie i sprawdzonych wyników. Metodologiczny sceptycyzm, ale też postęp $w$ wielu dziedzinach nauki sprzyjały umocnieniu przeświadczenia o stałej progresji wiedzy i tym samym stałym postępie ludzkości, która dąży ku „świetlanej” przyszłości. Postęp w naukach szczegółowych zdeprecjonował pozycję filozofii, która przede wszystkim utraciła miejsce królowej nauk, a w następnej kolejności podważono jej naukową wartość w ogóle. Nowy oświeceniowy porządek społeczny miał zostać ugruntowany nie na filozoficznych, ale na naukowych podstawach, to znaczy miał być efektem dynamicznego postępu i rozwoju cywilizacyjnego. Rewolucja francuska ukazała więc nowego człowieka "politycznego”, czyli człowieka, który jawi się przede wszystkim jako obywatel i któremu niezbywalnie przysługują prawa wyrażane hasłem "równość, wolność i braterstwo". Wedle takiego schematu wspólnota polityczna to rezultat świadomego uczestnictwa każdego członka danej społeczności jako obywatela w życiu wspólnotowym. Poszczególni ludzie-indywidua świadomie i wolnym aktem zawierają umowę i to ona stanowi podstawę zawiązania wspólnoty. W takim paradygmacie polityczność człowieka jest skutkiem aktu dokonanego przez z natury wolne jednostki i z tego powodu ze swej istoty jest „a-naturalna”. Można więc powiedzieć, że nierealna lub fikcyjna, co jednak nie sprawia, iż w konsekwencji nieważna, bezwartościowa lub całkowicie nieweryfikowalna, bo sprowadzona jedynie do opinii, poglądu czy też do pewnego typu „marzycielstwa”. 
W tak zarysowany schemat $\mathrm{w}$ pewien sposób wpisuje się Immanuel Kant, dla którego punktem wyjścia wszelkiego namysłu nad światem, człowiekiem czy w końcu politycznością był problem określenia kondycji i statusu metafizyki, a w szerszym znaczeniu kwestia znalezienia rozwiązania sporu o związek teorii z praktyką. Kant był zdania, że czasy, w których żyje - epoka Oświecenia, „stulecie Fryderyka” (Kant, 2012, s. 47) - są wiekiem wychodzenia człowieka ze stanu niepełnoletności, w który zresztą popadł ze swojej winy (Kant, 2012, s. 49-50), i przejściem w stan właściwej mu dojrzałości, co skłania do przypuszczenia, że również polityczność, życie wspólnotowe, wreszcie państwo są eksplikacjami owego dojrzewania. Dotychczasowe deprecjonowanie filozofii uważał on przy tym za niepożądane, choć sama filozofia na pewno wymagała naprawy, aby wyzbyć się tego, co doprowadziło ją na drogę jałowych sporów. Wielkim skandalem dla Kanta było to, że filozofia tak mocno odstała od nauk szczegółowych, co ostatecznie ją deprecjonuje. Naprawienie takiego stanu stało się dla niego wielkim zadaniem, któremu poświęcił cały swój intelektualny wysiłek i którego efektem okazało się przedstawienie projektu filozofii krytycznej, filozofii transcendentalnej. Krytycyzm Kanta wymierzony został w tradycję filozoficzną. Jednocześnie autor postawił sobie o wiele ambitniejsze zadanie, ponieważ ów krytycyzm implikował filozoficzną reformę, która miała z niej stworzyć naukę, a zatem podnieść jej wartość i postawić na równi z innymi dynamicznie rozwijającymi się naukami szczegółowymi (głównie z czystym przyrodoznawstwem i czystą matematyką). Pomijając szczegóły rozważań filozoficznych Kanta w ramach transcendentalizmu i krytycyzmu, chciałbym skupić uwagę na opisaniu intuicji królewieckiego myśliciela w odniesieniu do rzeczywistości politycznej.

\section{PROJEKT WIECZYSTEGO POKOJU IMMANUELA KANTA}

Szczególne znaczenie dla dylematu teorii i praktyki ma niewielki, późny tekst Kanta z roku 1795 pod tytułem Ku wieczystemu pokojowi. Filozoficzny projekt (zob. Kant, 2012, s. 333-392). Dzieło nie doczekało się wielu opracowań i nie wywołało dużego zainteresowania badaczy 
dorobku politycznego filozofa. Można powiedzieć, że przeważa opinia, iż nie jest to tekst wybitny, co sprawia, że umieszcza się go raczej na pograniczu dokonań naukowych i publicystycznych Kanta razem $\mathrm{z}$ innymi pismami polemicznymi.

Tymczasem dzieło to porusza problem zaprowadzenia pokoju na poziomie ogólnoświatowym, zawiera więc kosmopolityczny postulat zakończenia wszelkich wojen oraz konfliktów i zapoczątkowania niezmiennego oraz niepodważalnego stanu pokojowego. Autor przy tym konstruuje swój tekst jako swoisty plan, którego realizacja ma przyczynić się do osiągnięcia wskazanego w tytule celu, czyli wiecznego pokoju. Szczególnie ważne wydaje się to, że poszczególne elementy owego planu formułowane są jako zalecenia i postulaty, są zatem bezwzględnie konieczne i niemożliwe do pominięcia, jeśli zakłada się realizację światowego pokoju (Höffe, 2001, s. 161-166; Saner, 1995, s. 44-45). Prowadzi to do oczywistego wniosku mianowicie-Kantowski plan, a zasadniczo poszczególne jego punkty, przyjmują postać formalnych imperatywów, które z jednej strony opisują konieczne warunki dla pokoju w sposób wyczerpujący, a z drugiej strony wymagają bezwzględnej wykonalności ${ }^{5}$.

Należy pamiętać, że Kantowski esej, a ogólniej ujmując zawarty w nim postulat ustanowienia pokoju w skali światowej, trzeba czytać, mając w pamięci główne założenia jego filozofii praktycznej, to znaczy przede wszystkim autonomię i niezależność ustaleń, praw uzyskanych drogą rozumową od stanu faktycznego czy też realnych relacji zachodzących w świecie. Innymi słowy, Kant był przekonany, że na przykład w odniesieniu do ludzkich działań absolutnie nie wolno formułować ogólnych zasad ich postępowania (tzn. tego, co powinno się czynić), opierając się na tym, jak ludzie faktycznie postępują. Podobnie droga do światowego pokoju nie może być oparta na analizie aktualnego stanu relacji między państwami i formułowaniu na tej podstawie prawideł rządzących relacjami między podmiotami międzynarodowymi. Owa analiza i wnioski konieczne dla relacji

5 Zob. np. sześć preliminarnych artykułów, które zdaniem Kanta są niezbędnymi warunkami pojawienia się wiecznego pokoju (Kant, 2012, s. 333-337). Można znaleźć różne stanowiska odnośnie do przywołanych preliminariów i ich znaczenia dla Kantowego projektu. Bezwzględną ich wartość podkreśla na przykład Karl Jaspers (1968, s. 124). Z kolei ich znaczenie pomniejsza Borries (1973, s. 203). 
założonego celu powinny wynikać z niepodważalnych czysto rozumowych ustaleń. W rezultacie koncepcja Kanta wydaje się być przyjętym z góry teoretycznym ustaleniem sposobu uzyskania wiecznego pokoju w skali międzynarodowej, który abstrahuje od realnego doświadczenia i praktycznego zastosowania. Weryfikowalność teorii nie odbywa się zatem w rzeczywistym jej zastosowaniu, ale wynika z jej logiczno-racjonalnej poprawności (jest postulatem praktycznego rozumu).

W rozważaniach politycznych Kanta dominuje więc czysto racjonalna analiza, co bezpośrednio wynika z założeń jego filozofii. Reguła nieodwoływania się do stanu aktualnego i tego, jak ludzie (lub państwa) w rzeczywistości postępują miała zdaniem filozofa zapobiegać tworzeniu wszelkiego rodzaju sofizmatów, które bez wątpienia powstają gdy miesza się ze sobą fakty z obowiązkami, to znaczy, gdy konieczne do realizacji warunki, których ważność nie wynika z praktyki lub empirii próbuje się uzasadnić odwołując się właśnie do stanu faktycznego i do doświadczenia. Wskazana zasada wydaje się oczywista i niepodważalna, dodatkowo odgrywa ważną rolę w obszarze moralności, którą Kant właśnie na podstawie imperatywów konstruuje. Ludzkie postępowanie powinno być na przykład dobre nie z tego powodu, że tak postępuje się w rzeczywistości (przynajmniej większość ludzi tak czyni), lecz dlatego, że taki postulat wypływa z rozumu i tylko rozumowo jest uzasadnialny. W tym znaczeniu Kantowskie postulaty polityczne niejako abstrahują od historycznych i empirycznych faktów (co jednak nie oznaczało, że filozof ignorował i nie interesował się bieżącą sytuacją polityczną było wprost przeciwnie). W jego perspektywie namysłu nad zagadnieniami politycznymi (czyli odnoszącymi się do relacji międzyludzkich, wspólnotowych) zdecydowany nacisk postawiony został na postulatywność i w konsekwencji na cel konieczny do osiągnięcia, pomijał zaś zupełnie empiryczne, rzeczywiste czy naturalne, jak kto woli, źródło jego pochodzenia (zastanowię się jeszcze nad kwestią, czy ów cel faktycznie musi zostać osiągnięty, żeby wskazywać na jego zasadność) . Innymi słowy można powiedzieć, że dla Kanta nie miały żadnego znaczenia rozważania zmierzające do ustalenia, skąd się coś wzięło, a najważniejsze było uzasadnienie, czemu owo coś służy (Szczepański, 2017, s. 172-173; Cavallar, 1992, s. 100-132).

Takie spojrzenie niesie jednak ze sobą pewne niedogodności, które zmuszają do krytycznego spojrzenia na proponowane przez autora 
polityczne rozwiązania (dotyczy to również projektu wieczystego pokoju). Wojciech Buchner (1996, s. 48) pisze o nich następująco:

W filozofii moralnej reguła ta [tzn. że na podstawie postępowania ludzi nie wolno formułować praw jak powinni czynić - J.S.] miała zapobiegać wszelkim sofizmatom jakie powoduje pomieszanie obowiązków z faktami [...]. Jednakże, w zastosowaniu do oceny konkretnych wydarzeń politycznych, reguła ta nie zapobiegała temu pomieszaniu, lecz stwarzała moralno-historiozoficzną perspektywę, w której fakty tracą swoją autentyczną wymowę. W tej właśnie perspektywie rewolucja francuska postrzegana była przez Kanta, wbrew faktom, jako element pokojowego planu samej natury i przyczynek do ustanowienia w przyszłości międzynarodowego ładu prawnego.

Okazuje się zatem, że czysto teoretyczny namysł, pomijający jakiekolwiek odniesienie i liczenie się z faktami, pomimo tego, że jest znakomicie uzasadnialny logicznie i rozumowo wykazuje, lub przynajmniej może wykazywać, wiele trudności przy próbie wdrożenia go w życie. Ma to miejsce nawet przy założeniu, które można odczytać jako intencję Kanta na przykład w przywołanym eseju Ku wieczystemu pokojowi, że owo wprowadzenie w życie politycznego projektu światowego pokoju wcale nie musi nastąpić, aby ów projekt uważać za prawdziwy i tym samym za pewien obowiązek. Rodzi się tu naturalny rozdźwięk między doskonałym teoretycznym planem a praktyką życia codziennego, co może być samo w sobie głęboko rozczarowujące. Pojawiającą się dodatkowo konsekwencją analizowanej koncepcji jest jej specyficzne nastawienie. Dla badacza pokroju Kanta najważniejsze - i w zasadzie jedyne warte uwagi było badanie dalekosiężnych konsekwencji danego politycznego wydarzenia, a mało interesujące wydawały się towarzyszące mu aktualne fakty. Nastawienie takie może nieść w sobie trudne do zaakceptowania uznanie za nieważne bieżących konsekwencji wydarzeń politycznych, w tym często dokonywanych politycznie czynów, które moralnie są jednoznacznie naganne. Innymi słowy, rodzi się tu niebezpieczeństwo zgody na przykład na łamanie podstawowych praw moralnych w imię zasady mówiącej, że cel uświęca środki. Choć Kanta trudno posądzić aż o taki radykalizm, to niemniej nie sposób odmówić mu pewnej postawy naiwności politycznej, którą sam nazywał stanem marzycielskim. W kontekście oceny jego projektu wieczystego pokoju i marzycielskiego tonu tego postulatu 
znakomicie ujął to Sylwester Chauvelot w liście skierowanym do filozofa. Pisał bowiem tak:

Rodzaj Pańskiej głębokiej wiedzy, a zwłaszcza Pańskie ostatnie osobliwe dzieło [chodzi właśnie o tekst $K u$ wieczystemu pokojowi - J.S.], dowodzą niezbicie, że w większym stopniu miał Pan do czynienie z umarłymi niż żywymi. Prostoduszność Pańskiego umysłu i czystość Pańskiego serca każą Panu sądzić, że wszyscy ludzie posiadają lub zdolni są posiadać Pańskie cnoty (Buchner, 1996, s. 49).

Kant w ocenie autora listu okazuje się więc niemal naiwnym politycznym ignorantem, na dodatek wykazującym marzycielskie przeświadczenie o rozsądku i racjonalności wszystkich ludzi, co w efekcie pozwala formułować racjonalne postulaty jako imperatywy. Być może Chauvelot uchwycił pewną słabość koncepcji Kanta, jednak wydaje się, że chybiony jest zarzut o jego naiwności, a tym bardziej braku związku między teoretycznymi dociekaniami autora a bieżącymi wydarzeniami politycznymi (co Chauvelot rozumiał jako większy kontakt Kanta z umarłymi niż żywymi). Opierając się na tekście Ku wiecznemu pokojowi postaram się to wykazać.

Rzeczony esej dotyczy relacji międzynarodowych, szczególnie idei kosmologicznej odnoszącej się do ostatecznego uporządkowania owych stosunków. Przejawia się to w postawionym już w tytule postulacie zaprowadzenia wiecznego pokoju, który winien stanowić istotę i sedno wszelkich relacji między najwyższymi podmiotami relacji międzynarodowych, to znaczy między państwami. Kluczem do właściwego ujęcia Kantowskiej idei wydaje się poprawne rozpoznanie zamiaru autora, który wyraża już w samym tytule dzieła - ku, czyli w stronę wieczystego pokoju. Intencją filozofa jest zatem przedstawić taki plan lub, jak sam pisze, taki projekt, który opisuje, co należy spełnić, aby relacje między państwami miały sens i były właściwie ugruntowane, to znaczy realizowały dążenie do zaprowadzenia stałego porządku - wieczystego pokoju. $Z$ takim rozpoznaniem intencji autora wiążą się jednak wątpliwości, które dobrze przedstawił Jakub Szczepański (2017, s. 169), uwzględniając szerszą perspektywę całości namysłu Kanta, szczególnie jego poglądy polityczne i pojawiający się problem rzeczywistych motywów, które skłoniły go do napisania tego tekstu "czy stanowi on poważną propozycję, niemalże wzoru czy szablonu przyszłych traktatów pokojowych, czy też jest nieomal 
żartem filozofa, który w wieczny pokój po prostu nie wierzył?" (por. Brandt, 1996, s. 72-86). Ważne w tym względzie wydaje się zwrócenie bacznej uwagi na sam tytuł omawianego dzieła. W pełnej jego wersji mamy bowiem po pierwsze zaznaczone podążanie ku wiecznemu pokojowi, a w podtytule autor sygnalizuje, że jest to "filozoficzny projekt". Innymi słowy, Kant wskazuje czytelnikowi, że wychodząc od stanowiska filozoficznego sporządził projekt tego, w jaki sposób powinno się dojść do osiągnięcia stanu wiecznego pokoju. I być może nawet nie takie znaczenie ma przeanalizowanie zasadności poszczególnych elementów składowych owego projektu, jak problem, co w ogóle oznacza projekt filozoficzny. W szerszym ujęciu bowiem kwestia ta odnosi się do badanego tu zagadnienia relacji teorii do praktyki (filozofii do polityki).

We wprowadzeniu Kant pisze, że sam główny tytuł Ku wieczystemu pokojowi jest określeniem satyrycznym pochodzącym z szyldu wiszącego nad jakąś holenderską karczmą. Jego satyryczny wydźwięk podkreśla znajdujący się przy napisie rysunek cmentarza, co miałoby sugerować, że wieczysty pokój pomiędzy ludźmi może być osiąnięty tylko $\mathrm{w}$ razie ich śmierci, zatem znajduje się poza możliwością realizacji w doczesnym życiu. W szerszym ujęciu można powiedzieć, że idea wieczystego pokoju w przestrzeni politycznej wydaje się czysto nierealna, ponieważ byłby on osiągalny tylko wtedy, gdy znikną wszelkie antagonizmy między państwami, a te ustaną ostatecznie wówczas, gdy owe państwa znikną. Kant zdaje sobie z tego sprawę i przypisuje ten problem do realnego stanu relacji międzyludzkich:

czy ów satyryczny napis z szyldu holenderskiego karczmarza [...] odnosi się do ludzi w ogóle, czy w szczególności do nigdy nie sytych wojen przywódców państw, czy może tylko do filozofów śniących ów słodki sen, może pozostać nierozstrzygnięte (Kant, 2012, s. 333).

Autor wskazuje więc, że idea wiecznego pokoju może wystąpić albo w satyrycznym wymiarze, albo u nie traktowanych poważnie filozofów-teoretyków, którzy tworzą zupełnie nierealne plany, albo też odnosić się do opanowanych przez rządzę władzy polityków-praktyków, którzy, kierując się nieposkromionym pragnieniem, zawsze będą wywoływać wojny, aby nasycić swe polityczne pożądanie. Nie sposób zatem rozstrzygnać do kogo pismo to jest skierowane, ale można wskazać, że dla Kanta ważne pozostaje tu 
ukazanie konieczności poszukiwania związku między sferą czysto racjonalną i czysto praktyczną. Marek Siemek (2002, s. 109) pisze o tym następująco:

tutaj [tzn. w omawianym piśmie] niemal całkowicie zaciera się granica między "czystym" rozumem praktycznym (utożsamianym z moralnością w ścisłym sensie) a jedynie „stosowanym”, a więc takim, który odnosi się do wszystkich innych dziedzin ludzkiego życia w społeczeństwie i w historii, przede wszystkim zaś do polityki (por. Brandt, 1996, s. 74).

Zatem plan wprowadzenia wieczystego pokoju między wspólnotami ludzi (państwami), choć ma czysto spekulatywne źródło, a więc jawi się jako „marzycielski” plan filozofów lub też jest skutkiem „marzenia” jakichś polityków, którzy wykraczają poza jedynie praktyczne uprawianie polityki, może być potraktowany wbrew swemu żartobliwemu, satyrycznemu wydźwiękowi jako poważna propozycja uwzględniająca praktyczne zastosowanie. Jest to o tyle ważne, gdyż w zasadzie apriorycznie wyznaczone racjonalne zasady, prawa normujące relacje na poziomie międzynarodowym, swoje roszczenie do bezwzględnej ważności uzyskują tylko przy uwzględnieniu możliwości zastosowania ich w praktycznych dziedzinach. Innymi słowy, zdaniem Kanta moralność i polityka muszą być wzajemnie związane, ponieważ bezwzględnie od siebie zależą - teoretyczny namysł nad wieczystym pokojem ma sens wyłącznie wtedy, gdy związany jest z praktycznym jego wprowadzeniem. Tym samym filozofowi chodzi tu o zachowanie bezwzględnej obowiązywalności, a takowa występuje tylko w wypadku, gdy przybiera postać uniwersalnych, ogólnych zasad, w których nie bierze się pod uwagę materialnie określonych celów każdorazowych działań ludzkich, a więc pomija się jednostkowe przypadki występujące w realnych sytuacjach (Siemek, 2002, s. 110). Kant przywołuje więc satyryczny szyld „Ku wieczystemu pokojowi”, aby dobrze określić istotę jego filozoficznego projektu, który zakłada plan na zrealizowanie czegoś, co jeszcze nie istnieje, ale do czego można i należy usilnie dążyć. Tekst ten nie opowiada więc "o" wieczystym pokoju, ale podaje warunki konieczne do jego zrealizowania, pokazuje pewną drogę do przebycia, aby ów cel zrealizować. Tylko w takiej sytuacji następuje weryfikacja wartości rozumowej konstrukcji. 


\section{POLITYCZNE MARZENIA FILOZOFA}

Satyryczny wydźwięk projektu Kanta może mieć wszak jeszcze dodatkowe znaczenie, na które zwraca uwagę Jakub Szczepański. Okazuje się bowiem, że w pewnym sensie „wykpienie” przez autora swego projektu może stanowić swego rodzaju zabezpieczenie przed spodziewanymi atakami polityków-praktyków, dla których cały ów pomysł może być nie tylko śmiechu warty, lecz winien wzmóc czujność jako niebezpieczne, bo niezweryfikowane praktycznie zamierzenie prowadzące jedynie do katastrofy (Szczepański, 2017, s. 171: Höffe, 1995, s. 17). Taki sens miałoby sformułowanie Schulweisen, to znaczy „szkolni mędrkowie, którzy śnią jakiś słodki sen" (süßen Traum träumen) lub oddają się jakiemuś marzycielstwu. Czysty teoretyk jest więc kimś na kształt jakiegoś marzyciela, mędrka, który wbrew faktom przedstawia jakieś nierealne plany, projekty. Kant wyraźnie wskazuje, że pojawia się tu rozdźwięk i lekceważący stosunek polityka-praktyka do filozofa-teoretyka. Jak się wydaje, $\mathrm{z}$ taką sytuacją mamy niezmiennie do czynienia również w naszych czasach, w których politycy całkowicie ignorują głosy teoretyków niepolityków, gdyż są przeświadczeni, że wiedzą zdecydowanie lepiej, co w praktycznym obszarze polityki czynić. Filozof zarazem ostrzega przed zbytnim optymizmem wynikającym z poruszania się w czysto teoretycznym obszarze. Nazywa to owym „słodkim snem” lub „słodkim marzeniem”. Niebezpieczeństwo tu istniejące wynika z faktu zbytniego oddania się marzeniom lub pragnieniom będącymi skutkiem przekroczenia przez rozum swych kompetencji, a to zawsze prowadzi do uprawiania niebezpiecznego marzycielstwa (Szczepański, 2017, s. 171-172). Kant jawi się więc nie tylko jako dociekliwy myśliciel, ale też jako wytrawny obserwator realnego życia, który doskonale dostrzega fakt, że teoria niezwiązana z praktyką jest nic nie warta. Zarazem jednak rozumowanie to działa w drugą stronę, ponieważ praktyka bez teorii traci wszelkie swe podstawy ${ }^{6}$. Ze wskazanej zależności wynika, że właściwie ujęta teoria nie jest i nie może być zupełnie oddzielona od praktyki, choć nie znaczy to wcale, że winna

$6 \quad$ Kant w dziele pod tytułem O porzekadle: to może być słuszne w teorii, ale nic nie warte w praktyce definiuje teorię i praktykę poprzez ich wzajemne przenikanie (zob. Kant, 2012, s. 267-268). 
być czymś na kształt zsumowania poszczególnych wywiedzionych z praktycznych działań reguł. Właściwa teoria według Kanta musi być uogólnieniem praktyki, zatem musi mieć w sobie logiczną możliwość praktycznego zastosowania. Praktyka zaś nie jest właściwa, gdy opiera się wyłącznie na doraźnym, szczegółowym działaniu, lecz winna być działaniem zgodnym z teoretycznym wzorcem (Szczepański, 2017, s. 172). Bez wątpienia przedstawiony postulat raczej nie zostanie zaakceptowany przez praktyków-polityków. Pozostaje zatem rozumowym założeniem opartym na niepodważalnych, zatem absolutnie prawdziwych postulatach moralnych apriorycznie uzyskanych na drodze rozumowej, niemających wiele wspólnego z bieżącymi realiami politycznych zachowań ludzi, co jednak, zdaniem Kanta, wcale nie podważa ich ważności i konieczności. Wprost przeciwnie, stają się one zasadami, którymi winien kierować się człowiek, gdyż określają wymiar jego człowieczeństwa, zatem w tym sensie są niezbywalnie związane z naturą człowieka. Człowiek więc tak jak nie jest w stanie uciec przed swoją natura, podobnie nie jest w stanie odrzucić zasad moralnych, które są w nim („,prawa moralne we mnie"), nawet gdyby swym postępowaniem im zaprzeczał. Więcej - zaprzeczając owym prawom, potwierdza ich istnienie, zatem też apodyktyczną ważność. Na tych zasadach konstruuje Kant ramy życia społecznego, co wyraża przyjmowana przez niego charakteryzująca człowieka cecha ",aspołecznej towarzyskości”. Najwyższym stadium owego życia społecznego jest istnienie państwa, które reprezentuje konieczne do przestrzegania prawo. Stąd państwo Kanta to Rechtstaat - państwo prawa. Relacje między państwami to najwyższy poziom relacji społecznych, w którym obowiązują te same zasady co w relacjach międzyludzkich. W tym wymiarze wszelkie realne działania państw oparte są na idei pokoju, bowiem nawet jeśli konkretne państwo dąży do wojny po to, aby zrealizować swój partykularny cel, to mimo wszystko podstawą możliwości takiego działania jest przyjęcie istnienia pokoju jako stanu właściwego lub pożądanego. O powyższym zdaniem Kanta dobrze świadczy bezsporny fakt prowadzenia na przykład „wojen sprawiedliwych" lub „obronnych”. Możliwe jest też notoryczne ukrywanie przez państwa swych agresywnych planów i nieprzyznawanie się do prowadzenia polityki wojennej lub dążenia do wywołania wojny albo wprost przeciwnie maskowania swych prawdziwych planów chęcią zaprowadzenia lub 
ustanowienia pokoju. Stan pokoju jest zatem apriorycznie zakładany jako właściwy poziom (moralnie uzasadnialny) relacji międzynarodowych, co nie znaczy jednak, że w kwestii jego uczynienia ludzkość wykazuje jakieś postępy. $Z$ tej perspektywy Kant zdecydował się więc na sporządzenie planu realizacji tego postulatu i co przy tym ważne, postulat ten jako aprioryczny plan w sensie ścisłym jest teoretycznym konstruktem, jednak z możliwością jego zastosowania w praktyce? Należy przy tym wyraźnie uświadomić sobie zamysł autora - projekt wieczystego pokoju jest ",marzeniem sennym”, ideą powstałą w głowie myśliciela-teoretyka; żadne doświadczenie, żaden realny fakt nie potwierdza jego słuszności i nie daje nadziei na jego realizację, nie jest jednak bezsensowna, irracjonalną mrzonką. Wieczysty pokój jest niezbywalnym postulatem życia międzynarodowego i jego teoretyczny plan swą siłę czerpie nie z dotychczasowej „wykonalności” czy też z ogólnie dostrzegalnego postępu w jego realizacji, ale z tkwiącej $\mathrm{w}$ wewnętrznej strukturze tego planu opartego na moralnych regułach człowieczeństwa (wymieńmy je tutaj - przede wszystkim sprawiedliwość i wolność) niezachwianej sile jego wykonalności, czyli po prostu na możliwości jego praktycznego zrealizowania. Szczepański (2017, s. 178) pisze w związku z tym o Kantowskim postulacie:

Pokój w ogóle jest więc hipotezą o charakterze praktycznym, która pojawia się na poziomie fundowania wszelkich struktur politycznych. Mówiąc o państwie, zakładamy pokój jako jedną z podstawowych racji jego istnienia. Mówiąc o relacjach międzynarodowych, chcąc

$7 \quad$ Kant nie dostrzega sprzeczności między teorią i praktyką czy też moralnością a polityka, nawet jeśli z subiektywnej perspektywy jest inaczej. W ostatniej części swego tekstu eksplikuje to wprost, pisze bowiem: „Obiektywnie (w teorii) nie ma zatem żadnej sprzeczności pomiędzy moralnością a polityką. Natomiast subiektywnie (w egoistycznych ludzkich skłonnościach, które jednak dlatego, że nie są ugruntowane w maksymach rozumu, nie mogą zostać nazwane praktyką) sprzeczność ta utrzymuje się i może się utrzymywać zawsze, gdyż służy ona za osełkę cnoty, której prawdziwe męstwo (zgodnie z zasadą: tu ne cede malis, sed contra audentior) polega $\mathrm{w}$ niniejszym przypadku nie tyle na twardym postanowieniu przeciwstawienia się nieszczęściom i ofiarom, jakie w danym wypadku należy wziąć na siebie, lecz na tym, by śmiało spojrzeć w oczy o wiele bardziej niebezpiecznej, kłamliwej, zdradzieckiej, obłudnie mędrkującej, złej zasadzie w nas samych, każącej usprawiedliwiać wszelkie wykroczenia pod pretekstem słabości ludzkiej natury, a także na tym, by jej podstępność przezwyciężać" (Kant, 2012, s. 367). 
nie chcąc, pozostajemy z tą, jak ją określa Kant, hipotezą. Wieczny pokój staje się więc sensem naszego działania, również w relacjach międzynarodowych, i musimy działać w imię pewnej wiary, że być może ów idealny stan uda się osiągnąć, bo przecież nie udowodniliśmy, że jest on niemożliwy do realizacji. Używając innego terminu ze słownika Kanta, wieczny pokój jest idea, którą z moralnego obowiązku powinniśmy próbować zrealizować.

Okazuje się więc, że ostateczna moc teoretycznego postulatu światowego pokoju tkwi w fakcie, że jest on możliwy do wykonania, a może jeszcze inaczej - że nie zawiera on niczego, co dawałoby niezachwiana pewność, że jest niemożliwy do realizacji. To ostatnie wydaje się kluczowe, ponieważ być może jest najlepszym wyrażeniem rozumienia przez Kanta związku teorii z praktyką albo filozofii z polityką. Filozof może być „marzycielem”, podobnie zresztą jak nie-filozofowie, jednak owe „marzycielstwo" należy właściwie rozumieć - nie jest ono na pewno zupełnie nierealną wizją urojonych pragnień, niemożliwych do zrealizowania, zatem nie jest rezultatem na przykład ignorancji czy politycznego dyletanctwa. Owo marzycielstwo wynika bowiem ze spoglądania „dalej”, z nastawienia na poszukiwanie ostatecznych i niepodważalnych zasad regulujących stosunki polityczne (Gerhardt, 1996, s. 467-469). Takowe zaś zdaniem Kanta mogą być uzyskane tylko na apriorycznej drodze rozumowania. Na ich uformowanie nie mają zatem wpływu ani bieżące politycznie realne fakty, ani dotychczasowa praktyka polityczna, ani też skuteczność konkretnego politycznego działania. Obowiązuje bowiem tu wskazana wcześniej Kantowska reguła, że powinności czy obowiązki człowieka nie mają żadnego związku z jego konkretnym postępowaniem, to znaczy praktyka ludzkich zachowań nie może determinować wyznaczania powszechnych zasad właściwego postępowania. Jeśli tak spojrzymy na marzyciela, to Kantowego projektu nie potraktujemy jak żartu, mimo odwołania się przez niego do satyrycznego szyldu. Jest to bowiem "filozoficzny projekt", co znaczy, że jest jak najbardziej poważną propozycją wykazującą sposób uzgodnienia z sobą moralności (filozofii) i polityki. Marek Siemek (2002, s. 112) zaznacza przy tym, że rzeczony podtytuł: „filozoficzny projekt” szczególnie mocno podkreśla wagę Kantowskiej propozycji. Tekst ten nie jest jakimś urojeniem umysłu, który mocno przekroczył zakres swoich kompetencji, nie jest też czysto publicystyczną wypowiedzią filozofa, 
który niejako „przy okazji” składa jakąś propozycję, nawet z pewnym przymrużeniem oka (satyryczną). Dla Kanta projekt pokoju jest niezbywalną częścią jego filozoficznego namysłu, a nawet więcej - jest koniecznym uzupełnieniem jego filozoficznych rozważań, ponieważ "filozofię tę dopełnia oraz wzbogaca".

\section{IDEA WIECZYSTEGO POKOJU JAKO ZWIAZZEK MORALNOŚCI I POLITYKI}

Etyka (moralność) i polityka jawią się w transcendentalnym powiązaniu. Moralność udziela powszechności, opisuje powinności i obowiązki, którym podlegają wszyscy. W ostateczniej postaci wyrazem owej koniecznej powszechności jest powszechne prawo, co z kolei sankcjonuje istnienie państwa prawa (Rechtstaat). W owym państwie ścierają się dwie ludzkie dominanty, z jednej strony warunki życia wspólnotowego zawsze regulowane przez powszechne prawo, $\mathrm{z}$ drugiej indywidualne skłonności do działania wedle jedynie tylko własnego interesu. Kant buduje na tym gruncie również relacje międzypaństwowe: powinny być one regulowane powszechnymi prawami, zarazem jednak każde państwo działa we własnym ukrytym interesie, który nie zawsze jest zgodny z interesem innych. Jakkolwiek przebiega ten proces, to zawsze działa zasada, że w sferze polityki występuje przymus intersubiektywnie powszechnej ważności, co sprawia, że wszelki niemoralnie działający podmiot stara się ukryć swe działania przed innymi. Posuwa się zatem do kłamstwa i zatajenia, a ogólnie mówiąc do działania niejawnego, ukrytego (Williams, 1992, s. 222-225). Takiemu szkodliwemu procesowi zapobiega powszechność jawnej formy działania, co powoduje, że działający niejawnie musi liczyć się z sankcjami i karą. Wszystko to sprawia, że istnieje nieod parta potrzeba publicznej racjonalizacji i moralnego uprawomocnienia właściwych reguł rządzących relacjami między podmiotami życia politycznego. W tym znaczeniu należy odczytywać filozoficzny projekt międzynarodowego pokoju autorstwa Kanta. Konstruuje on zasady, reguły i maksymy budujące właściwie, zatem $z$ istoty transcendentalne, ale powszechnie ważne struktury relacji między państwowych. $W$ obszarze tym powinny działać właściwe podmioty, czyli „państwa celów”, w których panuje republikańska 
z istoty idea jedności obywatelstwa i zwierzchnictwa. Ustrój republikański wydaje się Kantowi jedynym w pełni wartym wszelkiego działania w przestrzeni politycznej. Realizując zatem projekt wieczystego pokoju urzeczywistnia także ideę republiki zachowującą doskonałą harmonię między intersubiektywną przestrzenią jawności w życiu publicznym a subiektywną, zindywidualizowaną sferą skłonności i usposobień. Według Marka Siemka (2002, s. 126-127) Kant osiaga w tym zgodność między moralnością i polityka, między marzeniami filozofa i realizmem polityka-praktyka. Filozof wnioskuje $\mathrm{z}$ tego swój sławny pogląd o przymusie prawa i państwie diabłów. Podporządkowanie bowiem swego praktycznego postępowania moralnym obowiązkom wcale nie musi wiązać się z osobistym przekonaniem i wewnętrzną akceptacją owych zasad (prawa). Innymi słowy, zachowania polityczne w sferze publicznej, które służą tworzeniu i umacnianiu powszechnego ładu ludzkiej wspólnoty, wynikają tylko i wyłącznie z przymusu prawa w imię wolności, co zdaniem Kanta bez problemu może skutecznie regulować międzypaństwowe relacje, a zatem prowadzić do ustanowienia ostatecznego ładu, czyli wiecznego pokoju. Zarazem dla filozofa nie ma żadnego znaczenia, czym kierują się indywidualnie (subiektywnie) poszczególne państwa. Same mogą być złożone nawet w niemoralnych jednostek, obywateli, co wcale nie przeszkadza, że państwa te są poprawne i dobre. Czytamy bowiem: „Problem zorganizowania państwa jest rozwiązywalny, mówiąc bez ogródek, nawet dla narodu diabłów (jeśli tylko posiadają one rozum)" (Kant, 2012, s. 374). Można więc ukonstytuować polityczne struktury zupełnie abstrahując od indywidualnego nastawienia i skłonności, co w rezultacie sprawia, że to nie cnoty, ale twarda konieczność (formalny przymus) stoi u podstawy każdego organizmu politycznego, w tym państwa. Podobnie ład pokojowego współżycia między państwami (nawet „państwami diabłów”) opiera się na niezbywalnym przymusie formalnych reguł ogólnych. Zarazem istnieje nierozerwalny związek między właściwym ustrojem owych państw (czyli republikańską zasadą obywatelskiego ustroju wolności jednostek podporządkowanych powszechnej obowiązywalności prawa) a trwałym pokojem. Wychodząc więc od dobrego ustroju republikańskiego można zbudować podstawy trwałych poprawnych relacji między „republikańskimi” państwami, a to prowadzi ostatecznie do ustanowienia niezbywalnego pokoju światowego. 
Postulat połączenia teorii z praktyką Kanta ma zatem jak najbardziej uzasadnialna, bo racjonalną podstawę. Związany jest logiczną koniecznościa, dlatego nie wymaga empirycznego potwierdzenia w dotychczasowej praktyce politycznej. Jego obowiązywalność o czym już wspominałem - nie wynika z analizy realnych zachowań ludzi w przestrzeni publicznej, a państwa w przestrzeni międzynarodowej. Być może Kant znajduje zatem klucz do dylematu pogodzenia politycznej teorii (marzenia, snu teoretyków) z politycznym realizmem (praktyką). Może zawierać się on w postulacie realizacji czegoś (w tym przypadku idei wieczystego pokoju) uzasadnionego tym, że nie zostało udowodnione, aby owo coś było niemożliwe do zrealizowania. W rezultacie więc jako możliwe powinno zostać podjęte jako cel działania. Wieczysty pokój jako projekt filozoficzny nie jest więc żartem zniedołężniałego filozofa, ale marzeniem, które winno determinować wysiłek ludzkości.

\section{BIBLIOGRAFIA}

Aron, R. (1996). Peace and War. A Theory of International Relations, trans. by R. Howard, A.B. Fox. New York: Doubleday.

Borries, K. (1973). Kant als Politiker. Aalen: Scientia Verlag.

Brandt, R. (1996). Quem fata non ducunt, trahunt: Der Staat, die Staaten und der friedliche Handel. W: Der Vernunftfrieden. Kants Entwurf im Widerstreit, Hrsg. K.-M. Kodalle. Würzburg: Königshausen \& Neumann, s. 61-86.

Buchner, W. (1996). Kant-państwo i prawo. Kraków: Aureus.

Cavallar, G. (1992). Pax Kantiana. Systematisch-historische Untersuchung des Entwurfs "Zum ewigen Frieden" (1795) von Immanuel Kant. Wien Köln - Weimar: Böhlau Verlag.

Gerhardt, V. (1996). Ausübende Rechtslehre. Kants Begriff der Politik. W: Kants in der Diskussion der Moderne. Hrsg. Y. Kato, G. Schönrich. Frankfurt a. M.: Suhrkamp, s. 464-478.

Höffe, O. (1995). Einleitung: Der Friede - ein vernachlässigtes Ideal. W: I. Kant, Zum ewigen Frieden. Berlin: Akademie, s. 1-28.

Höffe O. (2001). „Königliche Völker“. Zu Kants kosmopolitischer Rechts- und Friedenstheorie. Frankfurt a. M.: Suhrkamp Verlag.

Jaspers, K. (1968). Kants „Zum ewigen Frieden“. W: Aneignung und Polemik, Hrsg. H. Saner. München: Piper, s. 205-232. 
Kant, I. (2012). Dzieła zebrane. Tom VI. Pisma po roku 1781, red. M. Jankowski, T. Kupś, M. Marciniak, M. Żelazny. Toruń: Wydawnictwo Naukowe Uniwersytetu Mikołaja Kopernika.

Koslowski, P. (1985). Staat und Gesellschaft bei Kant. Tübingen: J.C.B. Mohr. Meier, Ch. (2012). Powstanie polityczności u Greków, przeł. M.A. Cichocki. Warszawa: Teoligia Polityczna.

Saner, H. (1995). Die negativen Bedingungen des Friedens. W: Immanuel Kant. Zum ewigen Frieden, Hrsg. O. Höffe. Berlin: Akademische Verlag, s. 43-67.

Siemek, M.J. (2002). Wolność, rozum, intersubiektywność. Warszawa: Terminus.

Stosunki międzynarodowe. Geneza, struktura, dynamika. Red. E. Haliżak, R. Kuźniar. Warszawa: Wydawnictwo Uniwersytetu Warszawskiego, 2006.

Szczepański, J. (2017). Filozofia polityczna Immanuela Kanta. Kraków: Wydawnictwo Uniwersytetu Jagiellońskiego.

Vasques, J. (1982), The Power of Power Politics: A Critique. New Jersey: Rutgers University Press.

Voegelin, E. (2013). Świat Polis, przeł. M.J. Czarnecki. Warszawa: Teologia Polityczna.

Williams, H. (1992). Morality or Prudence? Kant-Studien, 83, s. 222-225.

Copyright and License

This article is published under the terms of the Creative Commons Attribution - NoDerivs (CC BY- ND 4.0) License http://creativecommons.org/licenses/by-nd/4.0/ 